\title{
Clopidogrel Resistance in Stroke Cases
}

\author{
İnme Olgularında Klopidogrel Rezistansı
}

\begin{tabular}{|c|c|}
\hline \multicolumn{2}{|c|}{$\begin{array}{l}\text { 1ं istanbul University Faculty of Pharmacy, Department of Pharmacology, İstanbul, Turkey } \\
\text { 2istanbul Training and Research Hospital, Clinic of Neurology, ístanbul, Turkey } \\
\text { 3ístanbul Training and Research Hospital, Clinic of Radiology, Istanbul, Turkey }\end{array}$} \\
\hline ABSTRACT & ÖZ \\
\hline $\begin{array}{l}\text { Introduction: Clopidogrel treatment is one of the standard } \\
\text { treatments in terms of reducing mortality and morbidity in } \\
\text { patients with cerebrovascular disease diagnosed with large } \\
\text { artery atherosclerosis. However, resistance to clopidogrel } \\
\text { treatment is a significant problem today. In this study, we } \\
\text { aimed to retrospectively investigate clopidogrel resistance } \\
\text { (CR) and related factors in patients with detected large artery } \\
\text { atherosclerosis who were evaluated for cerebrovascular } \\
\text { disease. }\end{array}$ & $\begin{array}{l}\text { Amaç: Beyin damar hastalığı tanısı ile değerlendirilen ve büyük } \\
\text { arteraterosklerozu saptanan hastalarda mortalite ve morbititenin } \\
\text { azaltılması yönünden klopidogrel tedavisi standart tedaviler } \\
\text { içinde yer almaktadır. Bununla beraber klopidogrel tedavisine } \\
\text { karşı gelişen rezistans günümüzde önemli bir sorundur. Bu } \\
\text { çalışmada, beyin damar hastalığı nedeni ile değerlendirilen } \\
\text { ve büyük arter aterosklerozu saptanan hastalarda klopidogrel } \\
\text { rezistansının (KR) incelenmesi ve ilişkili faktörlerin retrospektif } \\
\text { olarak gözden geçirilmesi amaçlandı. }\end{array}$ \\
\hline $\begin{array}{l}\text { Methods: A total of } 96 \text { patients, including } 31 \text { females and } 65 \\
\text { males, were evaluated in the neurology and neuroradiology } \\
\text { clinics with the diagnosis of cerebrovascular disease. Age, } \\
\text { gender, presence of CR, and complete blood count values } \\
\text { [platelet count (PLT), platelecrit (PCT), mean platelet volume, } \\
\text { white blood cells, platelet distribution width] were evaluated. } \\
\text { Impedance Aggregometry was used to evaluate CR in the } \\
\text { study. The results were given as the area under the curve. An } \\
\text { adenosine diphosphate value higher than } 46 \mathrm{U} \text { was taken as a } \\
\text { resistance indicator. The relationship between blood tests and } \\
\text { CR was investigated. }\end{array}$ & $\begin{array}{l}\text { Yöntemler: Çalışmaya nöroloji ve nöroradyoloji kliniklerinde } \\
\text { beyin damar hastalığı tanısı ile değerlendirilen KR'nin } \\
\text { incelendiği, } 31 \text { kadın ve } 65 \text { erkek olmak üzere toplam } 96 \\
\text { hasta dahil edildi. Tüm hastaların yaş, cinsiyet, KR varlığı, } \\
\text { hemogram değerleri [platelet sayısı (PLT), platelekrit (PCT), } \\
\text { ortalama trombosit hacmi, beyaz kan hücreleri, trombosit } \\
\text { dağılım genişliği] retrospektif olarak değerlendirildi. } \\
\text { Çalışmada KR'nin değerlendirilmesinde impedans agregometri } \\
\text { kullanıldı. Sonuçlar eğri alında kalan alan cinsinden verildi. } \\
\text { Adenozin difosfat değerinin } 46 \text { U değerinden yüksek olması } \\
\text { rezistans göstergesi olarak alındı. KR varlığı ile incelenen tüm } \\
\text { parametreler arasındaki iliski değerlendirildi. }\end{array}$ \\
\hline $\begin{array}{l}\text { Results: CR was detected in } 33.3 \%(n=32) \text { of } 96 \text { patients. PLT } \\
(295.7 \pm 12.4) \text { and } P C T \text { values }(0.3 \pm 0.01) \text { were significantly } \\
\text { higher in patients with resistance than those without resistance } \\
(p<0.005) \text {. }\end{array}$ & $\begin{array}{l}\text { Bulgular: Toplamda } 96 \text { hastanın } \% 33,3 \text { 'ünde }(n=32) \text { KR } \\
\text { saptandı. Rezistans gösteren hastaların PLT }(295,7 \pm 12,4) \text { ve } \\
\text { PCT değerleri }(0,3 \pm 0,01) \text { rezistans göstermeyen hastalara göre } \\
\text { anlamlı oranda daha yüksek bulundu }(p<0,005) \text {. }\end{array}$ \\
\hline be used to predict CR. & $\begin{array}{l}\text { Sonuç: Bu çalışma yüksek PLT ve PCT değerlerinin KR'yi } \\
\text { öngörmede kullanılabilecek parametreler olduğunu } \\
\text { göstermektedir. }\end{array}$ \\
\hline & $\begin{array}{l}\text { Anahtar Kelimeler: Serebrovasküler hastalıklar, klopidogrel, } \\
\text { rezistans, platelet sayısı, platelekrit }\end{array}$ \\
\hline
\end{tabular}

\section{Introduction}

Platelets (PLTs) play an essential role in the development of ischemic stroke in terms of pathophysiology of thrombosis formation (1). Clopidogrel, an antithrombotic agent that inhibits PLT activation via adenosine diphosphate (ADP), has proven efficacy and safety in preventing recurrent ischemic strokes (1). Clopidogrel is a secondgeneration thienopyridine derivative prodrug and is converted to its active metabolite by cytochrome P450 enzyme system (mainly CYP2C19) 
in the liver. It shows its antithrombotic effect by irreversibly inhibiting the ADP-P2Y12 receptor located in the PLT membrane (2-4). Clopidogrel given at the standard dose does not show a complete P2Y12 antagonism; in other words, it inhibits ADP-mediated PLT aggregation by $50 \%$ (5). Therefore, some patients receiving clopidogrel therapy do not have an adequate therapeutic response to the drug, and this phenomenon is also described as clopidogrel resistance (CR). This phenomenon, also known as the absence of ADP-mediated PLT inhibition with the use of therapeutic doses of clopidogrel, can be attributed to individual variability in PLT response to clopidogrel treatment and may be associated with recurrent thrombotic events or poor prognosis incidence due to treatment insufficiency (6).

The frequency of patients who do not respond to clopidogrel treatment varies between $4-30 \%$, depending on the clinical use indications, the dose of the drug, the time of treatment initiation, and the test method to evaluate PLT functions $(5,7)$. Currently, CR is characterized by PLT function (a measurement of the degree of PLT aggregation induced by in vitro ADP) and genetic polymorphism analysis $(5,6)$. Evaluation of PLT function in cardiovascular and cerebrovascular diseases is important for predicting clinical outcomes and prognosis and determining the efficacy of antithrombotic therapy (2). In these studies, basal PLT parameters such as high PLT and plateletcrit (PCT), mean PLT volume (MPV), PLT distribution width (PDW), have been tried to correlate with $C R(8,9)$, but the results are still controversial $(10,11)$.

This study aimed to evaluate CR in patients diagnosed with large artery atherosclerosis during evaluation for stroke and to determine the routine biochemical parameters before clopidogrel treatment, thus evaluating whether biochemical markers could predict early PLT response and future clinical outcomes that might be associated with resistance.

\section{Methods}

Patients who were diagnosed clinically and radiologically with magnetic resonance imaging with cerebrovascular disease at İstanbul Training and Research Hospital, Clinic of Neurology and Neuroradiology between 29.09.2015 and 30.11.2017, and who were also diagnosed with large artery atherosclerosis or stenosis by brain computed tomography (CT) or MR angiography examinations during further evaluation were included in the study. A total of 96 patients (31 women and 65 men) with CR were evaluated retrospectively. The study was approved by the istanbul Training and Research Hospital Ethics Committee of clinical trials (decision no: 1687). As the study included retrospective file scanning, informed consent was not obtained from the patients.

The patients were divided into two groups as patients with $C R(C R+)$ and without CR (CR-). Age, gender, complete blood count parameters [PLT count, PCT, MPV, white blood cell count, PDW], and prothrombin time (PT-INR) were recorded retrospectively from patient files.

Patients with severe anemia, active hemorrhage, bone marrow disease, heparin-induced thrombocytopenia, blood transfusion, anticoagulant medication other than clopidogrel, or drug use that would affect PLT count were not included in the study.

\section{Evaluation of Clopidogrel Resistance}

Impedance aggregometry (Multiplate Analyzer, Dynabyte, Munich, Germany) was used to evaluate CR. For the test, blood was collected in $4 \mathrm{cc}$ tubes containing hirudin and incubated for 30 minutes at room temperature. Blood was diluted 1:2 with $0.9 \% \mathrm{NaCl}$ and stirred at 37 ${ }^{\circ} \mathrm{C}$ for 3 minutes. Then, $20 \mu \mathrm{l}$ of ADP $(6.4 \mathrm{Mmol})$ was added. Resistance changes caused by PLTs, which were aggregated and adhered to the electrodes in the test cell, were recorded with two pairs of electrodes. Increased resistance by PLTs adhering to the electrodes was converted to the aggregation unit (AU) by the device, and the time-aggregation graph was plotted. The area under the aggregation line Area Under the Curve, the parameter that best reflects platelet activity, was calculated. An ADP value of $>46 \mathrm{U}$ indicates no suppression, a value between 19-46 $U$ indicates adequate suppression, and $<19$ indicates over suppression.

In our study, there was no control group to determine the reference range of the PLT function test. Test results may vary between races, with each center determining its own reference range will give more accurate results.

\section{Statistical Analysis}

The data of our study were expressed as mean \pm standard error of the mean. The difference between CR+ and CR- patients was evaluated by the Mann-Whitney $U$ test. A chi-square test was used to compare qualitative data. $\mathrm{P}<0.05$ was considered statistically significant.

\section{Results}

\section{Impedance Aggregometry Results: Clopidogrel Resistance}

CR was detected in 32 (33.3\%) of 96 patients (31 women and 65 men) diagnosed with large artery atherosclerosis according to the impedance aggregometry results. The mean age of $\mathrm{CR}+$ patients was $70.4 \pm 1.5$ years, and the mean age of CR-patients was $68.9 \pm 1.4$ years. There was no difference between the two groups in terms of mean age $(p>0.05)$. Fifty-nine percent of $C R+$ patients were male, and $41 \%$ were female, and $72 \%$ of CR-patients were male, and $28 \%$ were female. There was no significant relationship between $C R$ and gender $(p=0.25)$ (Table 1). When $\mathrm{CR}+$ patients $(\mathrm{n}=32)$ were evaluated for possible co-morbidities, ten patients (31.25\%) were found to have both hypertension and diabetes, eight patients (25\%) had only hypertension, four patients (12.5\%) had only diabetes, and ten patients had no chronic disease.

\section{Biochemical Parameters}

Routine complete blood count parameters and PT-INR values requested from the patients were compared between CR+ and CR-patients and the values of both groups are summarized in Table 1. The mean ADP value of $\mathrm{CR}+$ patients was $67.5 \pm 4.4 \mathrm{U}$ and thrombin receptor activating peptide (TRAP) value was 116.6 \pm 4 , whereas the mean ADP value of CR-patients was 23.5 $\pm 3.5 \mathrm{U}$ and TRAP value was $88.7 \pm 3.5$ (Table 1). As these two parameters are indicators supporting the accuracy of the Impedance Aggregometry test, a significant difference was found between the two groups as expected $(p<0.05)$.

The mean PLT value of CR+ patients was 295.7 \pm 12.4 , and the mean PLT value of $C R$ - patients was $259.0 \pm 8.8$ (Figure $1 \mathrm{~A}$ ). The mean PCT value 
of $C R+$ patients was $0.3 \pm 0.01$, and the mean PCT value of CR-patients was $0.27 \pm 0.01$ (Figure $1 \mathrm{~B}$ ). Platelet and PCT values were higher in $\mathrm{CR}+$ patients, and a statistically significant difference was found between the two groups ( $p=0.02$ and $p=0.0015)$ (Figure 1, Table 1).

\section{Discussion}

At present, antiplatelet drugs are proven treatment of atherothrombotic stroke in the prevention of secondary stroke. In the last 30 years, studies have shown that aspirin, ticlopidine, clopidogrel, and dipyridamole are effective in preventing recurrent stroke in patients with atherothrombotic stroke $(12,13)$. Studies have shown that approximately $10-20 \%$ of patients undergoing antiplatelet therapy have a recurrent stroke (14). Repeated thrombotic event despite antiplatelet therapy raises antiplatelet drug resistance. Other commonly used definitions of this resistance are insufficiency of antiplatelet therapy, non-responsiveness, or inadequate efficacy.

In our study, 33.3\% of 96 cases had CR. Studies on CR have reported different rates. In the study of Notarangelo et al. (15), this rate was stated as 30\% and in the study by Wang et al. (7) as 11\%. In general, CR varies between $4-30 \%$ depending on the clinical indications, starting dose, maintenance dose, time to start treatment, and PLT function test methods (16).

Studies have reported higher CR in women $(17,18)$. However, although the rate of female patients in the $\mathrm{CR}+$ group was higher than the rate of female patients in the CR- group, no significant relationship was found between $C R$ and gender (Table 1). When the mean age was examined,
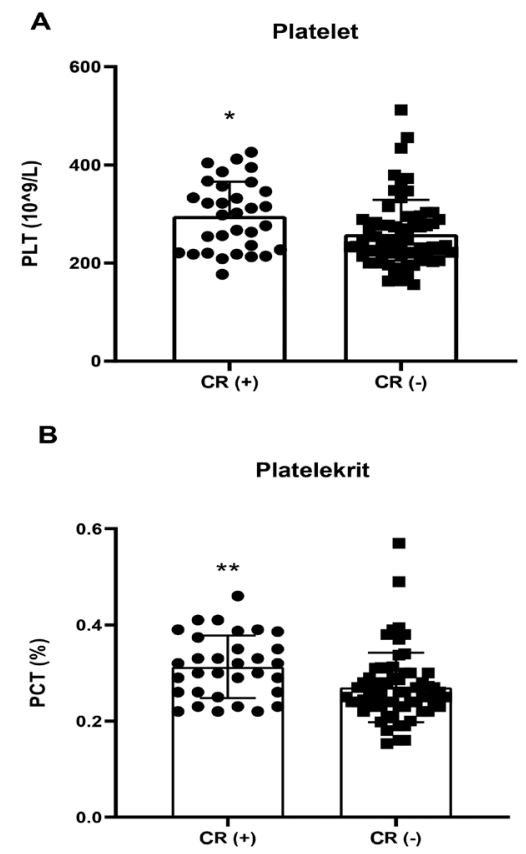

Figure 1. Platelet $A)$ and plateletcrit $B)$ values in patients with $(C R+)$ and without (CR-) clopidogrel resistance. Data were expressed as mean \pm standard error of the mean, and the comparison was made with the MannWhitney $U$ test. ${ }^{*} \mathrm{P}<0.05$. Individual data of $C R+$ and $C R$ - patients were placed in round and square bar graphs, respectively

PLT: platelet, PCT: plateletcrit, CR: clopidogrel resistance no significant difference was found between the $C R+$ and $C R$ - groups in support of previous studies $(17,18)$.

The main finding of our study was that the PLT and PCT values of the patients with CR were significantly higher than those without resistance. In studies conducted to date, baseline PLT values, which can easily be obtained from routine laboratory tests, are shown as simple and useful markers that can be used to predict CR (6). Our findings suggest that PLT count, and PCT, which is a measure of total platelet mass, can be used as parameters to predict CR.

Thrombus formation and PLT activation play an important role in the pathogenesis of ischemic cerebrovascular diseases $(19,20)$. Estimates of PLT volume and count give information about PLT function and activation (20). PLT is a parameter reflecting PLT production, function, and aging (8), and high PLT values are noteworthy in patients showing CR in support of our study (6). Therefore, patients with elevated PLT levels before treatment may be prone to thrombosis.

It is assumed that PCT shows PLT count circulating in a unit of blood, similar to the hematocrit value for erythrocytes (21). In our study, PCT values were significantly higher in patients with CR. It has been proposed that high PCT values can be used as a useful parameter in predicting coronary slow-flow phenomenon associated with cardiovascular pathologies such as recurrent angina pectoris, acute myocardial infarction, and hypertension, and may be considered as a marker for more aggressive antiplatelet therapy (22). In support of this hypothesis, the findings of our study suggest that PCT value can be used as another parameter that can be evaluated together with the PLT count in predicting CR. However, larger scale and comprehensive studies are needed to establish the relationship between CR and high PCT values.

MPV is another commonly used parameter to evaluate PLT size and function (8). In the studies performed, MPV values were found to be

\section{Table 1. Clinical and laboratory features of CR+ and CR-patients}

\begin{tabular}{|l|l|l|l|}
\hline Parametre & $\mathbf{C R}+(\mathbf{n}=32)$ & $\mathbf{C R}-(\mathbf{n}=\mathbf{6 4})$ & $\mathbf{p}$ \\
\hline Age & $70.4 \pm 1.5$ & $68.9 \pm 1.4$ & NS \\
\hline Female, $n(\%)$ & $12(41)$ & $18(28)$ & NS \\
\hline MPV (fL) & $10.7 \pm 0.2$ & $10.4 \pm 0.1$ & NS \\
\hline PLT (10^9/L) & $295.7 \pm 12.4 *$ & $259.0 \pm 8.8$ & 0.01 \\
\hline PCT (\%) & $0.3 \pm 0.01^{* *}$ & $0.27 \pm 0.01$ & 0.0015 \\
\hline PDW (\%) & $13.2 \pm 0.5$ & $14.4 \pm 1.8$ & NS \\
\hline HB (g/dL) & $12.9 \pm 0.3$ & $13.4 \pm 0.2$ & NS \\
\hline WBC (10^9/L) & $8.8 \pm 0.4$ & $8.2 \pm 0.3$ & NS \\
\hline RBC (10^12/L) & $4.5 \pm 0.1$ & $4.7 \pm 0.07$ & NS \\
\hline HCT (\%) & $39.4 \pm 0.8$ & $40.7 \pm 0.6$ & NS \\
\hline INR & $0.95 \pm 0.02$ & $1.02 \pm 0.04$ & NS \\
\hline ADP (U) & $67.5 \pm 4.4 * * *$ & $23.5 \pm 1.3$ & $<0.001$ \\
\hline TRAP (U) & $116.6 \pm 4 * * *$ & $88.7 \pm 3.5$ & $<0.001$ \\
\hline
\end{tabular}

Quantitative data were expressed as mean \pm SEM, and the comparison was made with the Mann-Whitney U test. ${ }^{*} p<0.05$. Qualitative data (age) were given as $n(\%)$ and evaluated by the chi-square test

CR: clopidogrel resistance, MPV: mean platelet volume, PLT: platelet count, PCT: platelecrit, PDW: platelet distribution width, HB: hemoglobin, WBC: white blood cells, RBC: red blood cells, HCT: hematocrit, INR: international normalized ratio, ADP: adenosine diphosphate, TRAP: thrombin receptor activating peptide 
significantly higher in patients with CR compared to patients responding to treatment $(23,24)$. In a prospective study by Li et al. $(25)$, PLT and MPV values were found to be significantly higher in the clopidogrel-resistant group in 152 coronary artery patients (CAD) treated with clopidogrel. It was observed that $\mathrm{CR}+$ patients had more cardiovascular events in the 53-month follow-up period, and it was concluded that the increase in PLT and MPV was a risk factor for the development of CR in CAD (25). In our study, no statistically significant difference was found between $C R+$ and CR-patients in terms of MPV, whereas the PLT value was significantly higher in the $\mathrm{CR}+$ group.

\section{Study Limitations}

The limitations of our study include the small number of patients and lack of evaluation of several related factors (especially CYP2C19 enzyme activity and genetic polymorphism, inflammation-related biochemical parameters such as C-reactive protein) due to the retrospective nature of our study.

\section{Conclusion}

We found a significant relationship between CR and PLT and PCT values in our study. This finding suggests that PLT and PCT values can be considered as parameters that can be used to predict CR. Considering that CR examination is costly and not performed in many centers, it may be appropriate to evaluate these findings with more large-scale prospective studies.

\section{Acknowledgment}

This study was carried out within the scope of the grade 5 Graduation thesis of Büşra Tuğba Özmen for Bachelor's degree in pharmacy.

Ethics Committee Approval: The study was approved by the İstanbul Training and Research Hospital Ethics Committee of clinical trials (decision no: 1687).

Informed Consent: As the study included retrospective file scanning, informed consent was not obtained from the patients.

Peer-review: Externally peer-reviewed.

Author Contributions: Concept - N.Ç., U.E.; Design - N.Ç., U.E.; Data Collection and/or Processing - N.Ç., B.T.Ö., Z.S.D., U.E., Ö.K.; Analysis and/or Interpretation - N.C.., U.E.; Literature Search - N.C.., B.T.Ö., Z.S.D., U.E.; Writing Manuscript - N.Ç., U.E.

Conflict of Interest: No conflict of interest was declared by the authors.

Financial Disclosure: The authors declared that this study received no financial support.

\section{References}

1. Kernan WN, Ovbiagele B, Black HR, Bravata DM, Chimowitz MI, Ezekowitz MD et al. Guidelines for the prevention of stroke in patients with stroke and transient ischemic attack: A guideline for healthcare professionals from the American Heart Association/American Stroke Association. Stroke 2014; 45: 2160-36.

2. Güray Y, Güray Ü, Korkmaz Ş. Klopidogrel direnci. Anadolu Kardiyoloji Dergisi 2009; 9: 231-7.
3. Savi P, Combalbert J, Gaich C, Rouchon MC, Maffrand JP, Berger Y, et al. The antiagregating activity of clopidogrel is due to a metabolic-activation by the hepatic cytochrome p450-1a. Thromb Haemost 1994; 72: 313-7.

4. Jafary FH, Kimmelstiel CD. Antiplatelet therapy in interventional cardiology: I. Newer oral antiplatelet agents. J Thromb Thrombolysis 2000; 9: 157-62.

5. Le Quellec S, Bordet JC, Negrier C, Dargaud Y. Comparison of current platelet functional tests for the assessment of aspirin and clopidogrel response. Thromb Haemost 2016; 116: 638-50.

6. Li W, Xie X, Wei D, Zhang S, Wu Y, Fu X, et al. Baseline platelet parameters for predicting early platelet response and clinical outcomes in patients with noncardioembolic ischemic stroke treated with clopidogrel. Oncotarget 2017; 8: 93771-84.

7. Wang TH, Bhatt DL, Topol EJ. Aspirin and clopidogrel resistance: an emerging clinical entity. Eur Heart J 2006; 27: 647-54

8. Du J, Wang Q, He B, Liu P, Chen JY, Quan H, et al. Association of mean platelet volume and platelet count with the development and prognosis of ischemic and hemorrhagic stroke. Int J Lab Hematol 2016; 38: 233-9.

9. Asher E, Fefer P, Shechter M, Beigel R, Varon D, Shenkman B, et al. Increased mean platelet volume is associated with non-responsiveness to clopidogrel. Thromb Haemost 2014; 112: 137-41.

10. Pujol-Moix N, Vazquez-Santiago M, Morera A, Ziyatdinov A, Remacha A, Nomdedeu JF, et al. Genetic determinants of platelet large-cell ratio, immature platelet fraction, and other platelet-related phenotypes. Thromb Res 2015; 136: 361-6.

11. Beyan C, Beyan E. Mean platelet volume may not be related to clopidogrel resistance in patients with acute coronary syndrome. Anadolu Kardiyol Derg 2014; 14: 405-6.

12. Tan C. Antitrombotik bir etkin madde içeren tablet formülasyonunun geliștirilmesi üzerine çalıșmalar, Gazi Üniversitesi Sağlık Bilimleri Enstitüsü, Farmosötik Teknoloji Anabilim Dalı, Yüksek lisans tezi, 2007.

13. Kılıç Çoban E, Xanmemmedow E, Soysal A. Klopidogrel direnci mevcut hastalarda eșlikçi komorbiditelerin ve kullanılan ilaçların etkilerinin sorgulanması. Türk Beyin Damar Hast Derg 2015; 21: 103-7.

14. Antithrombotic trialists collaboration. Collaborative metaanalysis of randomised trials of antiplatelet therapy for prevention of death, myocardia infarction, and stroke in hig risk patients. BMJ 2002; 324: 71-86.

15. Notarangelo MF, Bontardelli F, Merlini PA. Genetic and nongenetic factors influencing the response to clopidogrel. J Cardiovasc Med (Hagerstown) 2013; 14 Suppl 1: S1-7.

16. Siller-Matula J, Schror K, Wojta J, Huber K. Thienopyridines in cardiovascular disease: focus on clopidogrel resistance. Thromb Haemost 2007; 97: 385-93.

17. Sharma, RK, Erickson SW, Sharma R, Voelker DJ, Reddy HK, Dod H, et al. Platelet function testing to predict hyporesponsiveness to clopidogrel in patients with chest pain seen in the emergency department. Vasc Health Risk Manag 2013; 9: 187-93.

18. Bozbeyoglu E, Satilmis S, Aksu H, Yildirimturk O, Nurkalem Z. Impact of clopidogrel resistance on ST-segment resolution and no-reflow in acute myocardial infarction with ST-elevation patients treated with a primary percutaneous coronary intervention. Coron Artery Dis 2012; 23: 523-7.

19. Steinhubl SR, Moliterno DJ. The role of the platelet in the pathogenesis of atherothrombosis. Am J Cardiovasc Drugs 2005; 5: 399-408.

20. Oz II, Yucel M, Bilici M, Serifoglu I, Sayin R, Ilikhan SU, Acikgoz M. Is mean platelet volume a reliable marker to predict ischemic stroke in the follow-up of patients with carotid stenosis? J Stroke Cerebrovasc Dis 2016; 25: 404-9.

21. Bain BJ, Bates I. Basic haematological techniques. S.M. Lewis, B.J. Bain, I. Bates (Eds.), Dacie and Lewis practical haematology (9th ed.), Churchill Livingstone Edinburgh (2001), pp. 19-46. 
22. Akpinar I, Sayin MR, Gursoy YC, Aktop Z, Karabag T, Kucuk E, et al. Plateletcrit and red cell distribution width are independent predictors of the slow coronary flow phenomenon. J Cardiol 2014; 63: 112-8.

23. Choi DH, Kang SH, Song H. Mean platelet volume: a potential biomarker of the risk and prognosis of heart disease. Korean J Intern Med 2016; 31: 10091017.
24. Quan W, Chen Z, Yang X, Li J, Li X, Weng Y, et al. Mean platelet volume/platelet count ratio as a predictor of 90-day outcome in large artery atherosclerosis stroke patients. Int J Neurosci 2017; 127: 1019-27.

25. Li L, Han JL, Li HY, Qiao R, Yu HY, Zhang J. Clopidogrel resistance of patients with coronary artery disease and its correlation with platelet count and mean platelet volume. Zhonghua Yi Xue Za Zhi 2013; 93: 916-20. 